\title{
Genetic Diversity in the Environmental Conditioning of Two Sorghum (Sorghum bicolor L.) Hybrids
}

\author{
John J. Burke, Yves Emendack, Chad Hayes, Junping Chen \\ USDA-ARS, PA, Cropping Systems Research Laboratory, Lubbock, TX, USA \\ Email: john.burke@ars.usda.gov
}

How to cite this paper: Burke, J.J., Emendack, Y., Hayes, C. and Chen, J. (2018) Genetic Diversity in the Environmental Conditioning of Two Sorghum (Sorghum bicolor L.) Hybrids. American Journal of Plant Sciences, 9, 817-831.

https://doi.org/10.4236/ajps.2018.94063

Received: February 26, 2018

Accepted: March 25, 2018

Published: March 28, 2018

Copyright $\odot 2018$ by authors and Scientific Research Publishing Inc. This work is licensed under the Creative Commons Attribution International License (CC BY 4.0).

http://creativecommons.org/licenses/by/4.0/

\begin{abstract}
Sorghum metabolism continually adapts to environmental temperature as thermal patterns modulate diurnally and seasonally. The degree of adaptation to any given temperature may be difficult to determine from phenotypic responses of the plants. The present study was designed to see if the efficiency of quantum yield of photosystem II could be used as a measure of how well leaf tissue metabolism was able to withstand a prolonged respiratory demand caused by elevated temperatures. The efficiency of quantum yield values of Pioneer 84 G62 and Northrup King KS585 commercial sorghum hybrids showed that when the hybrids were grown in a $28^{\circ} \mathrm{C} / 20^{\circ} \mathrm{C}$ day/night cycle in the greenhouse or the field, Pioneer hybrid $84 \mathrm{G} 62$ withstood subsequent elevated thermal challenges better than Northrup King KS585. The same hybrids grown in a $39^{\circ} \mathrm{C} / 32^{\circ} \mathrm{C}$ day/night cycle showed similar efficiency of quantum yield values when thermally challenged. Water-deficit stress increased the heat resistance of the tissue raising the efficiency of quantum yield of both lines to the same level. Upon recovery from the water deficit stress the differential efficiency of quantum yield values between the two lines re-appeared. The data provided in this study suggest a metabolic advantage of Pioneer 84G62 to environmental thermal challenges compared with the Northrup King KS585.
\end{abstract}

\section{Keywords}

Sorghum, Sorghum bicolor L., Thermal Sensitivity, Adaptation

\section{Introduction}

Enzyme adaptations to temperature occur constantly as temperature patterns modulate diurnally, seasonally, or over centuries. These adaptations entail qua- 
litative and/or quantitative metabolic changes that often provide a competitive advantage, impact migration to new environments, and effect the survival of the species. Changes in isozymes or allozymes, changes in enzyme concentration, modification by substrate and effectors, and metabolic regulation of enzyme function without changing enzyme composition are all possible strategies for adaptation to changes in temperature.

The concept of thermal kinetic windows (TKW) arose from a desire to investigate temperature stresses in plants and the realization of a lack of knowledge about how to identify the optimal temperatures for metabolism. Thermal kinetic windows of optimal enzyme function were defined as the temperature range over which the value of the apparent $\mathrm{Km}$ was within $200 \%$ of the minimum apparent $\mathrm{Km}$ value observed for the enzyme [1]. The $200 \%$ cutoff value was used because previous studies [2] [3] had reported that enzymes could function optimally with $\mathrm{Km}$ values within $200 \%$ of the minimum $\mathrm{Km}$ value. The purpose of the thermal kinetic window was to provide a general indicator of the range of temperatures in which the optimal temperature for metabolism was located. The best correlative evidence of the validity of the TKWs comes from the determination of the temperature dependence of the reappearance of photosystem II variable fluorescence following illumination [4] [5]. The chlorophyll fluorescence functions as a natural indicator of the in vivo temperature characteristics of the plant. Although the TKWs were $5^{\circ} \mathrm{C}$ to $8^{\circ} \mathrm{C}$ in breadth, it was shown that these plants were only within the optimal temperature range of their TKWs for a fraction of the growing season [1]. Diurnal air temperature fluctuations of $10^{\circ} \mathrm{C}$ to $20^{\circ} \mathrm{C}$ are common occurrences throughout many growing regions. Because Thermal Kinetic Windows are only $5^{\circ} \mathrm{C}$ to $8^{\circ} \mathrm{C}$ in breadth, plants may be outside their optimal thermal range a large portion of every day.

Global climate change has been reported to increase climate variability with rapid thermal fluctuations and sporadic rainfall patterns [6]. It is essential that genetic diversity in abiotic stress tolerance be identified and favorable genes moved into the crops of the future. The current study investigated the level of genetic diversity of two commercial sorghum hybrids to thermal and water variability. The abiotic stress bioassay originally described by Burke [7] was used to evaluate the stress responses of these commercial sorghum hybrids.

\section{Material and Methods}

\section{Optimization of the Evaluation Protocol}

\section{1) Cultural Practices: Greenhouses:}

Sorghum (Sorghum bicolor L.) seeds were planted into two-gallon pots containing Sunshine Mix \#1 soil (Sun Gro Horticulture Distributors Inc., Bellevue, WA). The potting soil was saturated with Peters Professional water-soluble fertilizer (0.95 g.L $\mathrm{L}^{-1}$ 5-11-26 HYDRO-SOL [Scotts-Sierra Horticultural products Company, Maryville, $\mathrm{OH}$ ], supplemented with $0.475 \mathrm{~g} \cdot \mathrm{L}^{-1}$ calcium nitrate [Ca Hydro Agri North America, Inc., Tampa, FL], and $0.238 \mathrm{~g} \cdot \mathrm{L}^{-1}$ magnesium sulfate 
[Scotts-Sierra Horticultural products Company, Maryville, OH]). Three seeds were planted per pot and a total of five pots per hybrid per greenhouse were placed on benches and nutrients maintained using a non-recycling hydroponic watering system. One week following planting the seedlings were thinned to one plant per pot. $430 \mathrm{~W}$ high-pressure sodium lights (P. L. Light Systems, Beamsville, ON Canada) were used to maintain a $16 / 8 \mathrm{~h}$ photoperiod. Pots were flushed daily with $\mathrm{R} / \mathrm{O}$ water to prevent salt accumulation in the pots. The optimum range of air temperature for sorghum during the vegetative period is $26^{\circ} \mathrm{C}-34^{\circ} \mathrm{C}$ [8]; and during the reproductive period is $25^{\circ} \mathrm{C}-28^{\circ} \mathrm{C}$ [9] [10]. One greenhouse was set to provide a $28^{\circ} \mathrm{C} / 20^{\circ} \mathrm{C}$ day/night cycle (cool nights), and a second greenhouse was set to provide a $39^{\circ} \mathrm{C} / 32^{\circ} \mathrm{C}$ day/night cycle (heat stress). Sorghum hybrids evaluated were Pioneer $84 \mathrm{G} 62$ and Northrup King KS585. Water-stress was imposed on plants in the $39^{\circ} \mathrm{C} / 32^{\circ} \mathrm{C}$ day/night cycle greenhouse by cessation of watering for three days prior to measurement.

2) Cultural Practices: Field:

The sorghum (Sorghum bicolor L.) hybrids 84G62 and KS585 were planted in a North-South orientation using a John Deere 7300 MaxEmerge 2 VacuMeter Planter. The conventional tilled plots were two-61 meter rows of 84G62 and KS585 planted in an irrigated and a second set planted in rain fed plots. The irrigated plants were furrow irrigated biweekly. The rain fed plants received a total of $112 \mathrm{~mm}$ of rainfall during the first 80 days following planting, with half of that falling within the first week of planting. Air temperatures averaged a low temperature of $15.7^{\circ} \mathrm{C}$ and a high temperature of $30.3^{\circ} \mathrm{C}$ throughout the growing season.

3) Determination of the Thermal Sensitivity of the Efficiency of Quantum Yield ( FV Fm) of Sorghum Grown in Cool and Hot Environments.

Two Sorghum bicolor L. hybrids (84G62 and KS585) were grown in one greenhouse set to provide a $28^{\circ} \mathrm{C} / 20^{\circ} \mathrm{C}$ day/night cycle, and a second greenhouse set to provide a $39^{\circ} \mathrm{C} / 32^{\circ} \mathrm{C}$ day/night cycle as described under "Cultural Practices". Leaf punches $\left(1 \mathrm{~cm}^{2}\right)$ were taken from the widest portion of the leaf blade at 17:00 $\mathrm{h}$ and the fluorescence yield of photosystem II evaluated following a $16 \mathrm{~h}$ incubation at either $25^{\circ} \mathrm{C}, 28^{\circ} \mathrm{C}, 31^{\circ} \mathrm{C}, 34^{\circ} \mathrm{C}, 37^{\circ} \mathrm{C}, 40^{\circ} \mathrm{C}, 43^{\circ} \mathrm{C}$ or $46^{\circ} \mathrm{C}$ using a controlled eight-position thermal plate system for physiological investigations described by Burke and Mahan [11]. The efficiency of photosystem II quantum yield was determined using a Handy Pea Fluorometer (Hansatech Instruments Ltd., Norfolk, United Kingdom).

4) Water-Deficit Stress Effects on the Efficiency of Quantum Yield ( $\left.F_{V} / F m\right)$ :

The hybrids $84 \mathrm{G} 62$ and KS585 were used to evaluate the effect of water-deficit stress on field-grown and greenhouse grown sorghum. The plants were grown according the protocol outlined in the "Cultural Practices" section. Leaf punches were taken from the widest portion of the leaf blade, placed on moist filter paper on the temperature blocks of an electronically controlled eight-position thermal plate system [11]. The leaf punches were covered with Glad Cling Wrap ${ }^{\mathrm{TM}}$ (First 
Brands Corp., Danbury, CT) to prevent drying while still allowing gas exchange. Five replicate punches obtained from different plants in the irrigated and rain fed plots were evaluated $16 \mathrm{~h}$ after being placed at either $25^{\circ} \mathrm{C}, 28^{\circ} \mathrm{C}, 31^{\circ} \mathrm{C}, 34^{\circ} \mathrm{C}$, $37^{\circ} \mathrm{C}, 40^{\circ} \mathrm{C}, 43^{\circ} \mathrm{C}$ or $46^{\circ} \mathrm{C}$. The efficiency of photosystem II quantum yield was determined using a Handy Pea Fluorometer (Hansatech Instruments Ltd., Norfolk, United Kingdom).

5) Determination of Greenhouse Air Temperatures:

Greenhouse temperatures were determined using a HOBO Pro RH/Temp Data Logger (Onset Computer, Bourne, MA) placed within the canopy. Relative humidity and air temperatures were measured every 30 seconds over a $24 \mathrm{~h}$ period. Daily relative humidity levels ranged from $25 \%$ to $41 \%$ throughout the study.

6) Determination of Leaf Temperatures.

Leaf temperatures were obtained at $16: 30 \mathrm{~h}$ on day of year 218 using a hand-held infrared thermometer (Model 110, Everest Interscience, Chino Hills, CA).

\section{7) Data Processing.}

Statistical significance between genotypes and treatments were analyzed with studentized t-test through the statistical applications of Social Science Statistics (http://www.socscistatistics.com/tests/Default.aspx). Graphs were created using KaleidaGraph Version 4.1.3.

\section{Results}

\section{Determination of the Thermal Sensitivity of the Efficiency of Quantum Yield of Sorghum Grown in Cool and Hot Environments}

To evaluate how well-watered Pioneer 84G62 and Northrup King KS585 sorghum hybrids cope with distinct thermal regimes, plants were grown in greenhouses set to maintain air temperatures at either a $28^{\circ} \mathrm{C} / 20^{\circ} \mathrm{C}$ or $39^{\circ} \mathrm{C} / 29^{\circ} \mathrm{C}$ day/night cycle. Figure 1 is a graph of representative air temperatures from the two greenhouses. The $28^{\circ} \mathrm{C} / 20^{\circ} \mathrm{C}$ greenhouse (open circles) exhibited stable night temperatures at $20^{\circ} \mathrm{C}$, rising to $28^{\circ} \mathrm{C}$ over a $2 \mathrm{~h}$ period, and remaining at $28^{\circ} \mathrm{C}$ for $7-9 \mathrm{~h}$ before declining to $20^{\circ} \mathrm{C}$ over a $5 \mathrm{~h}$ period. The $39^{\circ} \mathrm{C} / 29^{\circ} \mathrm{C}$ greenhouse (closed circles) exhibited night temperatures between $29^{\circ} \mathrm{C}$ and $31^{\circ} \mathrm{C}$, rising to a range of temperatures between $37^{\circ} \mathrm{C}-39^{\circ} \mathrm{C}$, and then declining to the $29^{\circ} \mathrm{C}-31^{\circ} \mathrm{C}$ range over a $4 \mathrm{~h}$ period.

The efficiency of quantum yield of the sorghum hybrids KS585 (Figure 2(A)) and 84G62 (Figure 2(B)) grown under well-watered conditions and under air temperatures of either $28^{\circ} \mathrm{C} / 20^{\circ} \mathrm{C}$ day/night (A) or $39^{\circ} \mathrm{C} / 29^{\circ} \mathrm{C}$ day/night (B) was determined by incubating the tissue across a range of increasing temperatures (Figure 2(C)). The 84G62 and KS585 leaf samples from plants grown under the $28^{\circ} \mathrm{C} / 20^{\circ} \mathrm{C}$ day/night cycle exhibited efficiency of quantum yield values of 0.7 and 0.64 following a $16 \mathrm{~h} 25^{\circ} \mathrm{C}$ treatment. The $84 \mathrm{G} 62$ hybrid maintained an efficiency of quantum yield values of 0.72 , while the KS585 showed a decline in 


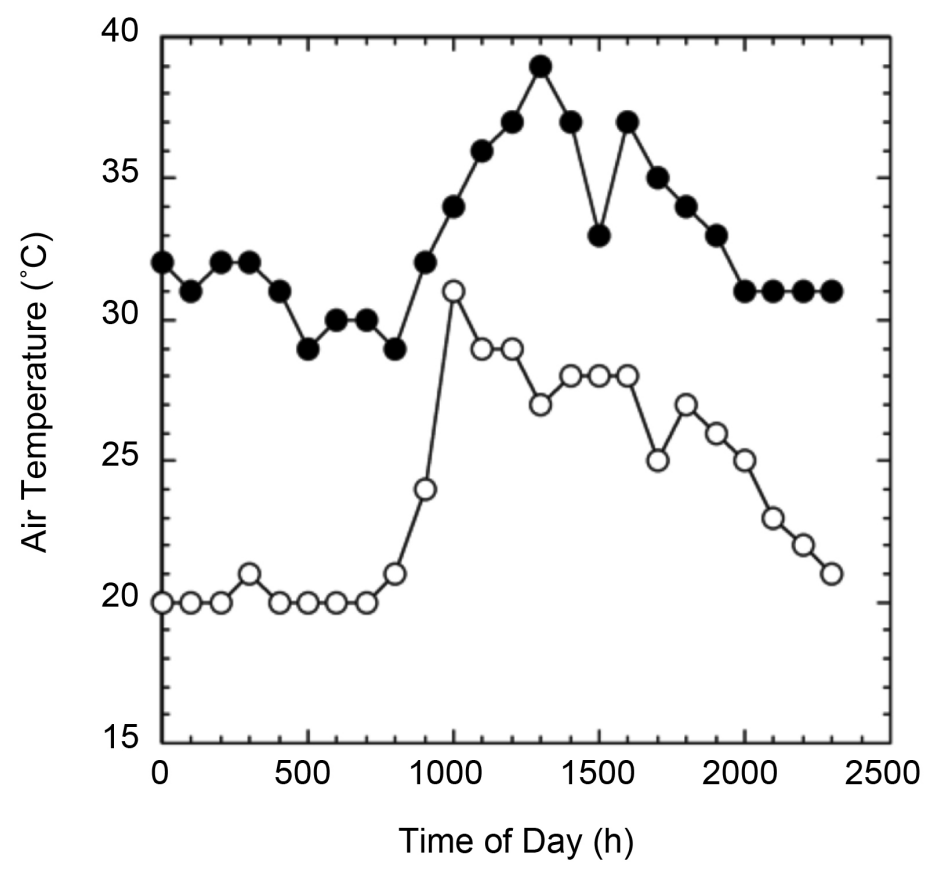

Figure 1. Graph of representative air temperatures experienced by the sorghum plants in a greenhouse set to provide a $28^{\circ} \mathrm{C} / 20^{\circ} \mathrm{C}$ day/night cycle (open circles) and a greenhouse set to provide a $39^{\circ} \mathrm{C} / 29^{\circ} \mathrm{C}$ day/night cycle (closed circles) prior to sampling.

efficiency of quantum yield to 0.47 following a $28^{\circ} \mathrm{C}$ treatment. Both hybrids showed declines in efficiency of quantum yield values at $31^{\circ} \mathrm{C}$ with the $84 \mathrm{G} 62$ exhibiting an efficiency of quantum yield value only slightly higher than the KS585. Similar efficiency of quantum yield values were observed with incubation temperatures of $34^{\circ} \mathrm{C}$ or above. The $84 \mathrm{G} 62$ and KS585 plants grown under the $39^{\circ} \mathrm{C} / 29^{\circ} \mathrm{C}$ regime had efficiency of quantum yield values of 0.78 and 0.77 respectively following a $25^{\circ} \mathrm{C}$ treatment (Figure 2). High efficiency of quantum yield values were observed with heat treatments of $25^{\circ} \mathrm{C}, 28^{\circ} \mathrm{C}, 31^{\circ} \mathrm{C}, 34^{\circ} \mathrm{C}$, and $37^{\circ} \mathrm{C}$ for both hybrids grown under the $39^{\circ} \mathrm{C} / 29^{\circ} \mathrm{C}$ regime. The efficiency of quantum yield values declined from 0.65 to 0.19 between $37^{\circ} \mathrm{C}$ and $40^{\circ} \mathrm{C}$. Clearly, sorghum hybrids from the $39^{\circ} \mathrm{C} / 29^{\circ} \mathrm{C}$ day/night greenhouse exhibited higher efficiency of quantum yield values across the range of incubation temperatures than those grown in the $28^{\circ} \mathrm{C} / 20^{\circ} \mathrm{C}$ day/night greenhouse.

The increased thermal protection suggested by the maintenance of high efficiency of quantum yield values in the $39^{\circ} \mathrm{C} / 29^{\circ} \mathrm{C}$ regime of Figure $2(\mathrm{C})$ made us wonder if the thermal protection would change in response to water-deficit stress. Figure 3 shows photographs of well-watered and water-deficit stressed KS585 (Figure 3(A)) and 84G62 (Figure 3(B)) on the day that the efficiency of quantum yield measurements were taken. Figure $3(C)$ shows the efficiency of quantum yield of well-watered plants and Figure 3(D) shows the efficiency of quantum yield of water-deficit stressed plants.

The water-deficit stressed hybrids shown in Figure 4(A) \& Figure 4(B) 


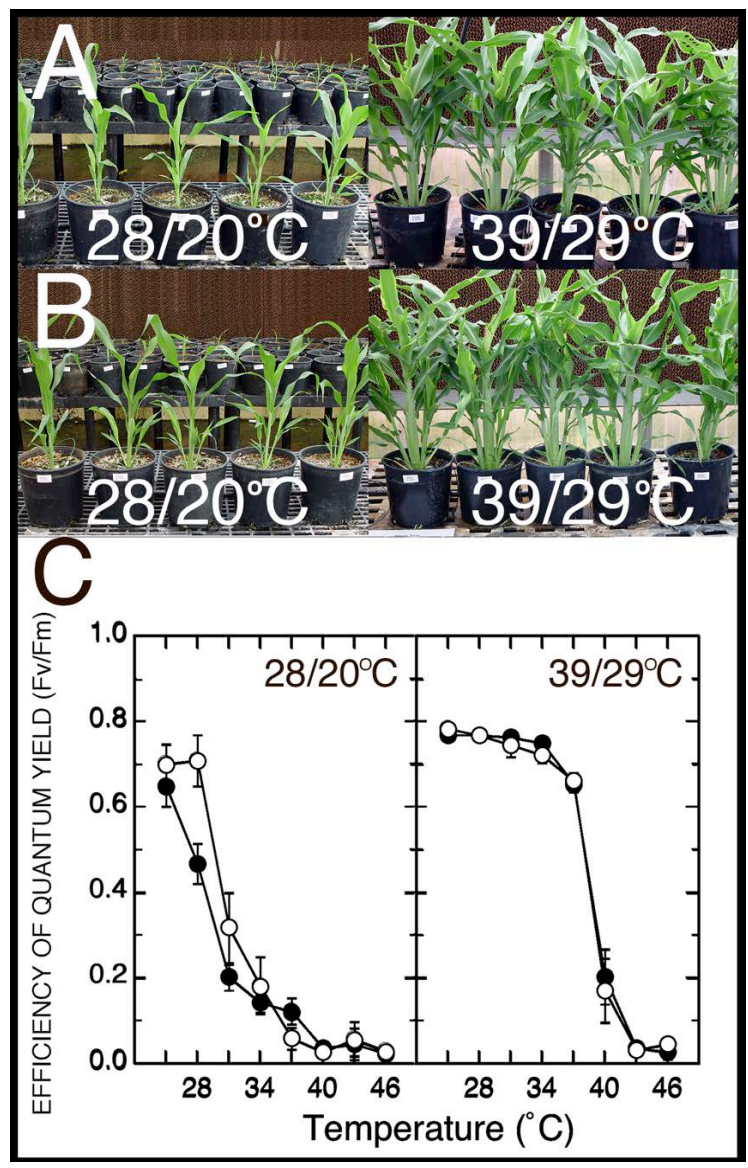

Figure 2. Photographs of (A) KS585 and (B) 84G62 sorghum hybrids grown under well-watered conditions and under air temperatures of either $28^{\circ} \mathrm{C} / 20^{\circ} \mathrm{C}$ day/night [plants on left of photographs] or $39^{\circ} \mathrm{C} / 29^{\circ} \mathrm{C}$ day/night [plants on right of photographs]. (C) Graph of the efficiency of quantum yield following a $16 \mathrm{~h}$ incubation across a range of temperatures for leaf samples from sorghum (hybrids: KS585 [closed circles] and 84G62 [open circles]) grown under well-watered conditions and under air temperatures of either $28^{\circ} \mathrm{C} / 20^{\circ} \mathrm{C}$ day/night or $39^{\circ} \mathrm{C} / 29^{\circ} \mathrm{C}$ day/night. Error bars represent standard error values $(n=5)$.

[plants on left of photographs] were re-watered [plants on right of photographs] immediately following the analysis of the efficiency of quantum yield values. Figure $4(\mathrm{C})$ is a graph of the efficiency of quantum yield values across a range of temperatures for leaf samples from sorghum (hybrids: $84 \mathrm{G} 62$ (open symbols) and KS585 (solid symbols)) water stressed (circles) and re-watered (squares) in the greenhouse. The efficiency of quantum yield indices of both hybrids declined following re-watering as evidenced by declines in efficiency of quantum yield values beginning at $37^{\circ} \mathrm{C}$ in the $84 \mathrm{G} 62$ hybrid and $34^{\circ} \mathrm{C}$ in the KS858 hybrid compared with the $40^{\circ} \mathrm{C}$ incubation required to reduce the efficiency of quantum yield values in the water-deficit stressed plants. 


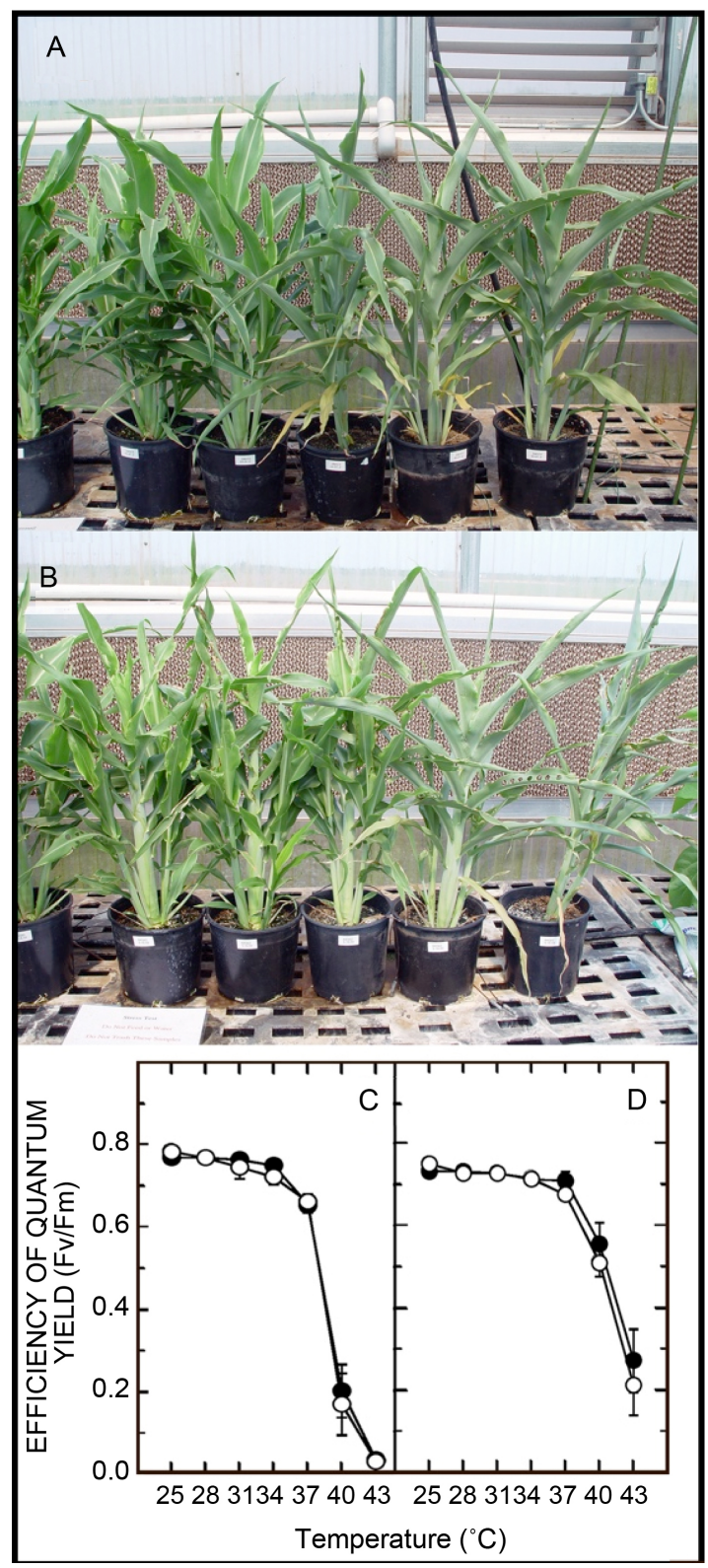

Figure 3. Photographs of (A) KS585 and (B) 84 G62 sorghum hybrids grown under well-watered conditions [plants on left of photographs] and water-deficit stressed sorghum [plants on right of photographs] grown at $39^{\circ} \mathrm{C} / 29^{\circ} \mathrm{C}$ day/night. (C) and (D) are graphs of the efficiency of quantum yield values following a $16 \mathrm{~h}$ incubation across a range of temperatures for leaf samples from sorghum (hybrids: KS585 [closed circles] and 84G62 [open circles]) grown under (C) well-watered conditions and from (D) water-deficit stress conditions. Error bars represent standard error values $(n=5)$.

Because the two sorghum hybrids showed differences in the efficiency of quantum yield indices when grown in the $28^{\circ} \mathrm{C} / 20^{\circ} \mathrm{C}$ day/night cycle greenhouse 


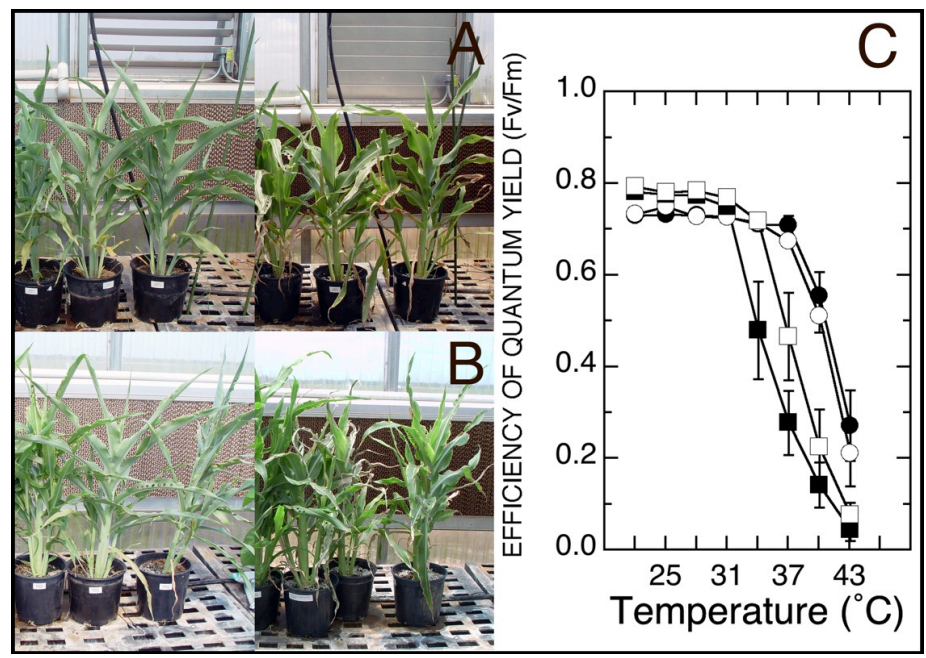

Figure 4. Photographs of (A) KS585 and (B) 84 G62 sorghum hybrids under water-deficit stress conditions [plants on left of photographs] and water-deficit stressed and re-watered sorghum [plants on right of photographs] grown at $39^{\circ} \mathrm{C} / 29^{\circ} \mathrm{C}$ day/ night. (C) is a graph of the efficiency of quantum yield values following a 16-h incubation across a range of temperatures for leaf samples from sorghum (hybrids: $84 \mathrm{G} 62$ (open symbols) and KS585 (solid symbols)) water-deficit stressed (circles) and re-watered (squares) in the greenhouse. Error bars represent standard error values $(n=5)$.

(Figure 2) and during the recovery from water-deficit stress (Figure 4), we chose to evaluate field-grown irrigated and dryland sorghum to see if similar differences occurred under field conditions. Figure 5 is a graph of representative air temperatures experienced by the sorghum plants in the $28^{\circ} \mathrm{C} / 20^{\circ} \mathrm{C}$ day/night cycle greenhouse and in the field during the course of the $24 \mathrm{~h}$ period prior to sampling. Greenhouse temperatures (open circles) and field temperatures (solid circles-day of year 118) are shown in Figure 5.

The $28^{\circ} \mathrm{C} / 20^{\circ} \mathrm{C}$ greenhouse (open circles) exhibited stable night temperatures at $20^{\circ} \mathrm{C}$, rising to $28^{\circ} \mathrm{C}$ over a $2 \mathrm{~h}$ period, and remaining at $28^{\circ} \mathrm{C}$ for $7-9 \mathrm{~h}$ before declining to $20^{\circ} \mathrm{C}$ over a $5 \mathrm{~h}$ period. The air temperatures in the field declined from $24^{\circ} \mathrm{C}$ at midnight to $18^{\circ} \mathrm{C}$ at $06: 00 \mathrm{~h}$. Both temperatures increased to a maximum of $30.5^{\circ} \mathrm{C}$ by $16: 00 \mathrm{~h}$. Temperatures between $26^{\circ} \mathrm{C}$ and $25^{\circ} \mathrm{C}$ were experienced between 17:00 $\mathrm{h}$ and 23:00 $\mathrm{h}$.

The photographs in Figure 6 show the phenotype of irrigated (left) and dryland (right) $84 \mathrm{G} 62$ and KS585. Figure 6(A) is a graph of the efficiency of quantum yield values following a $16 \mathrm{~h}$ incubation across a range of temperatures for leaf samples from sorghum (hybrids: 84G62 (open symbols) and KS585 (solid symbols)) grown under irrigated conditions in the field (A). Figure 6(B) is a graph of the efficiency of quantum yield values following a $16 \mathrm{~h}$ incubation across a range of temperatures for leaf samples from sorghum (hybrids: 84G62 (open symbols) and KS585 (solid symbols)) grown under dryland conditions in the field. The genetic differences in the efficiency of quantum yield indices 


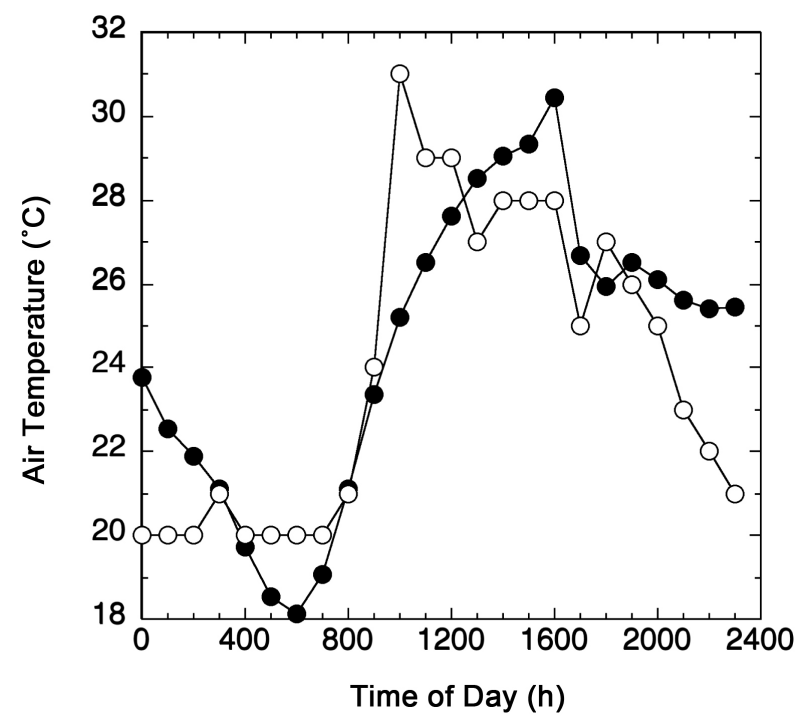

Figure 5. Graph of representative air temperatures experienced by the sorghum plants in a greenhouse and in the field during the course of the $24 \mathrm{~h}$ period prior to sampling. Greenhouse air temperatures are represented by the open circles, while the field air temperatures on day of year 218 are represented by the solid circles.

between the irrigated hybrids were apparent in the field grown material. The irrigated $84 \mathrm{G} 62$ was able to maintain the high efficiency of quantum yield value at temperatures $3^{\circ} \mathrm{C}$ higher than those of the KS585 (Figure 6(A)). Water-deficit stress in the field increased the efficiency of quantum yield indices of both $84 \mathrm{G} 62$ and KS585 to similar levels (Figure 6(B)). Efficiency of quantum yield values were maintained at 0.75 between $28^{\circ} \mathrm{C}$ and $34^{\circ} \mathrm{C}$ in both hybrids. A decrease in the efficiency of quantum yield values from $0.75^{\circ} \mathrm{C}$ at $34^{\circ} \mathrm{C}$ to values of 0.1 or lower at $37^{\circ} \mathrm{C}$ was observed for both hybrids.

Canopy temperatures were obtained immediately prior to harvesting field samples for analysis. Figure 7 is a graph of irrigated (open bars) and dryland (closed bars) 84G62 and KS585 canopy temperatures. Significant differences ( $p<$ $0.05)$ in canopy temperatures were observed between irrigated and dryland treatments and between hybrids within a treatment.

\section{Discussion}

The present study analyzed sorghum vegetative responses when grown in sub-optimal or supra-optimal thermal environments. It describes the characterization of plant responses to two distinct air temperature growing regimes. It further compares greenhouse and field responses of these two distinct sorghum hybrids. The stress bioassay first described by Burke [7] uses the efficiency of quantum yield of Photosystem II following a heat treatment as an in vivo indicator of cellular health. The efficiency with which absorbed light energy is harvested by photosynthesis is altered by a regulatory mechanism that determines 


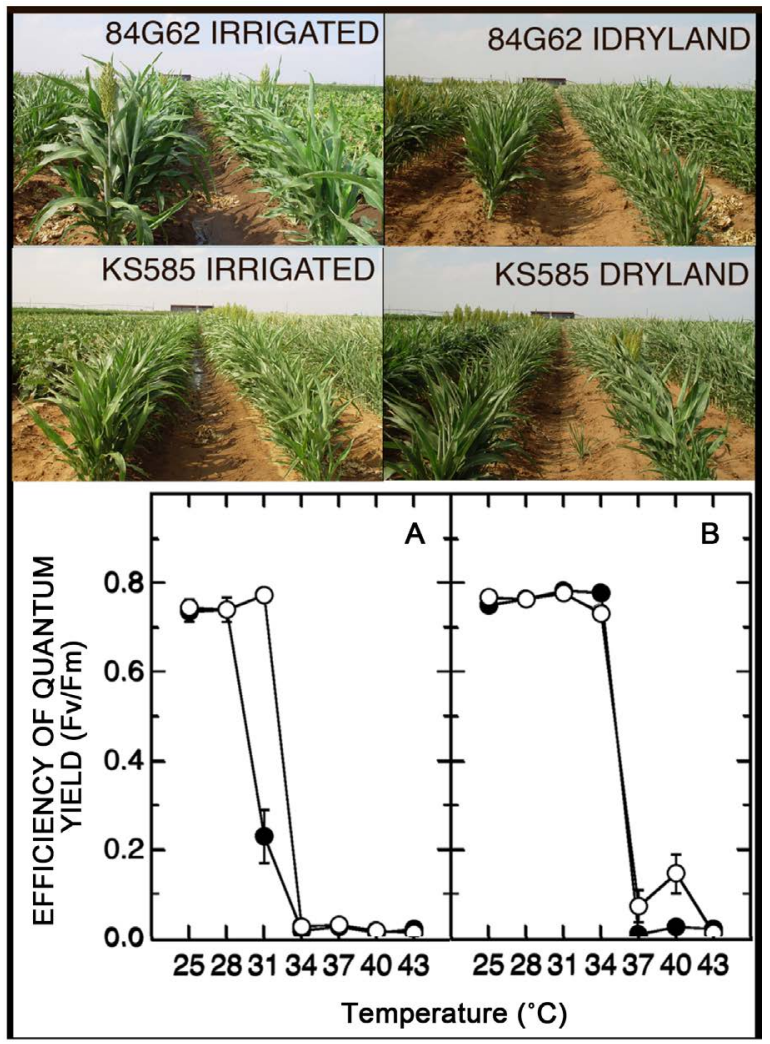

Figure 6. Photographs of irrigated (left) and dryland (right) 84G62 and KS585. The graph of the efficiency of quantum yield values following a $16 \mathrm{~h}$ incubation across a range of temperatures for leaf samples from sorghum (hybrids: 84G62 (open circles) and KS585 (solid circles)) grown under (A) irrigated conditions in the field or (B) dryland conditions in the field. Error bars represent standard error values $(n=5)$.

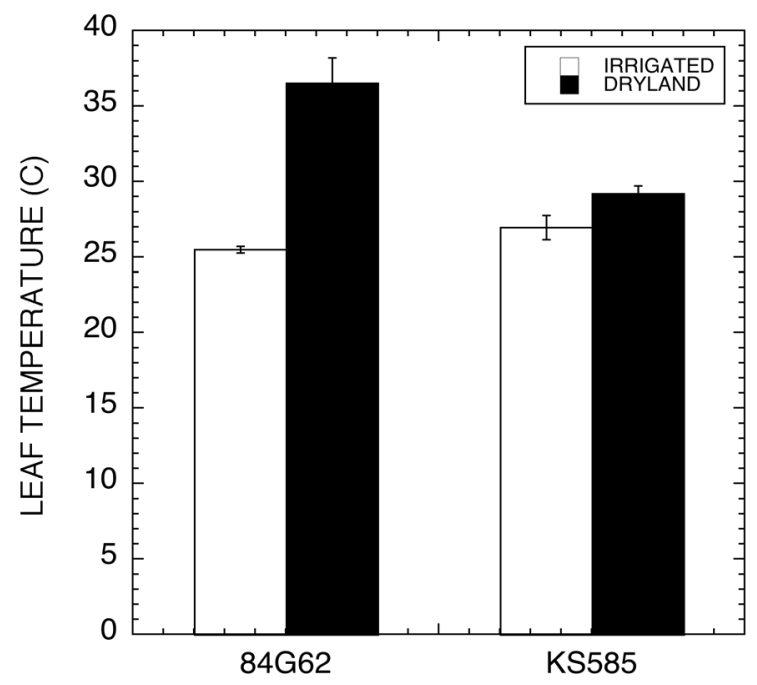

Figure 7. Graph of leaf temperatures of $84 \mathrm{G} 62$ and KS585 from irrigated and dryland field plots on Day of Year 218. Error bars represent standard error values $(n=5)$. 
how much excitation energy is used and how much is dissipated as heat under sub-optimal or supra-optimal thermal conditions [12]-[17]. The suboptimal thermal environment had night temperatures of $20^{\circ} \mathrm{C}$, well below the $27^{\circ} \mathrm{C}$ $30^{\circ} \mathrm{C}$ optimum previously reported in the literature [10] [18] (Figure 1). Additionally, the supra-optimal air temperature regime of $39^{\circ} \mathrm{C} / 29^{\circ} \mathrm{C}$ day/night was well above the optimum temperature during the day. The $28^{\circ} \mathrm{C} / 20^{\circ} \mathrm{C}$ day/night regime significantly reduced growth and development of both KS585 and 84G62 compared with the $39^{\circ} \mathrm{C} / 29^{\circ} \mathrm{C}$ day/night regime as seen in Figure 2(A) and Figure 2(B). Although the growth rate was reduced, the initial chlorophyll fluorescence levels $(\mathrm{Fv} / \mathrm{Fm})$ were 0.65 and 0.70 when incubated at $25^{\circ} \mathrm{C}$ for $16 \mathrm{~h}$. These $\mathrm{Fv} / \mathrm{Fm}$ levels were similar to the $\mathrm{Fv} / \mathrm{Fm}$ ' levels at $19^{\circ} \mathrm{C}$ and $21^{\circ} \mathrm{C}$ reported by Fielder et al. in a study of temperature-dependent sorghum growth during juvenile development [19]. Increasing the overnight challenge temperature to $28^{\circ} \mathrm{C}$ resulted in a decline in Fv/Fm to 0.46 in the KS585 compared with the 0.71 value of $84 \mathrm{G} 62$ (Figure 2(C)). Increasing temperatures further resulted in the decline in $\mathrm{Fv} / \mathrm{Fm}$ levels to similar levels at $34^{\circ} \mathrm{C}$ and above. Both hybrids exhibited greater growth at the $39^{\circ} \mathrm{C} / 29^{\circ} \mathrm{C}$ day/night regime compared to the $28^{\circ} \mathrm{C} / 20^{\circ} \mathrm{C}$ day/night regime (Figure $2(\mathrm{~A})$ and Figure $2(\mathrm{~B})$ ). Additionally, $\mathrm{Fv} / \mathrm{Fm}$ values were maintained at high levels following a $16 \mathrm{~h}$ exposure to $25^{\circ} \mathrm{C}$, $28^{\circ} \mathrm{C}, 31^{\circ} \mathrm{C}, 34^{\circ} \mathrm{C}$, and $37^{\circ} \mathrm{C}$. Similar efficiency of quantum yield temperature curves were seen for both KS585 and 84G62 hybrids (Figure 2(C)). The difference in thermal sensitivities of the efficiency of quantum yield in plants grown under the $28^{\circ} \mathrm{C} / 20^{\circ} \mathrm{C}$ day/night regime versus those grown under the $39^{\circ} \mathrm{C} / 29^{\circ} \mathrm{C}$ day/night regime is similar to previous reports of water-deficit stress responses in cotton [7].

Water-deficit stress reduces sorghum growth and increases the concentration of osmotic compounds within cells [20]. Because the efficiency of quantum yield assay measures in part the availability of cellular stored reserves to provide the energy needed to meet the high respiratory demand of the assay, then increased carbohydrates associated with water-deficit stress would be predicted to enhance the efficiency of quantum yield of the tissue. The results shown in Figure 3 support the hypothesis that increased osmolytes might enhance the thermal protection of the efficiency of quantum yield of the tissue. Leaf tissues from the water-deficit stressed plants maintained high efficiency of quantum yield indices following exposure to elevated temperatures compared to the irrigated controls Figure 3(C) and Figure 3(D). McCree et al. [20] showed that there was a large burst of respiration on re-watering, due to renewed synthesis of biomass from stored photosynthate. They reported that over the next 3 days following re-watering, osmotic adjustment was lost and the daily carbon balance returned to that typical of nonstressed plants. They concluded that osmotic adjustment allowed the stressed plants to accumulate biomass carbon throughout the cycle, with little additional metabolic cost. Carbon stored during stress was immediately available for biomass synthesis on re-watering. We investigated the 
thermal sensitivity of the efficiency of quantum yield from water-deficit stressed plants and from water-deficit stressed plants that had been re-watered (Figure 4). Figure $4(C)$ shows that the challenge temperature causing a reduction in the efficiency of quantum yield dropped from $40^{\circ} \mathrm{C}$ in water-deficit stressed plants to $37^{\circ} \mathrm{C}$ for $84 \mathrm{G} 62$ and $35^{\circ} \mathrm{C}$ for KS585. The difference in the thermal response curves between the two sorghum hybrids upon re-watering is similar to the difference observed in the plants grown under the $28^{\circ} \mathrm{C} / 20^{\circ} \mathrm{C}$ day/night regime (Figure 2(C)).

Historically it has been difficult to translate stress responses of greenhouse-grown plants to plant responses in the field. We evaluated field-grown $84 \mathrm{G} 63$ and KS585 plants grown with or without supplemental irrigation. Air temperatures in the field were similar to those of the $28^{\circ} \mathrm{C} / 20^{\circ} \mathrm{C}$ day/night greenhouse regime (Figure 5). The sensitivity of the efficiency of quantum yield to a $16 \mathrm{~h}$ thermal challenge was investigated in field-grown 84G62 and KS585 plants from irrigated and dryland plots. The thermal sensitivity curves of the field-grown 84G62 and KS585 plants (Figure 6) were similar to that obtained for the plants from the $28^{\circ} \mathrm{C} / 20^{\circ} \mathrm{C}$ day/night regime (Figure $2(\mathrm{C})$ ).

The results of the differential recovery from water-deficit stress between 84G62 and KS585 (Figure 3) made us question why there were different thermal sensitivities during recovery when there was no difference in the thermal sensitivity of the efficiency of quantum yield in the $39^{\circ} \mathrm{C} / 29^{\circ} \mathrm{C}$ day/night regime prior to withholding water. Canopy temperatures of the dryland plots (Figure 7) may provide some insight for the differential response observed in the greenhouse recovery study. The $84 \mathrm{G} 62$ hybrid exhibited a greater differential in canopy temperatures between irrigated and dryland plots than did the KS585. These results suggest that the $84 \mathrm{G} 62$ stomatal control mechanisms are more responsive to water-deficit stress resulting in higher canopy temperatures. It is interesting that the KS585 only exhibited a $2^{\circ} \mathrm{C}$ increase in canopy temperature in the dryland plots while the $84 \mathrm{G} 62$ had a $16^{\circ} \mathrm{C}$ differential in canopy temperatures. Phenotypically, the KS585 exhibited morphologies of water-deficit stressed sorghum in both the irrigated and dryland plots. It is interesting to speculate that the KS585 may have poorer stomatal responses to environmental signals than the $84 \mathrm{G} 62$ resulting in transpiration to partially continue under dryland conditions, thereby explaining the observed cooler canopy temperature in the dryland KS585. These findings may help to explain reported yield differences between these lines in other field studies. Grain sorghum performance tests in Hereford, Texas showed yield advantages for $84 \mathrm{G} 62$ over to the KS585 [21]. Clearly, other reports have shown strongly contrasting responses to water-deficit stress in sorghum germplasm [22] [23] [24] [25].

\section{Conclusion}

Global climate change has been reported to increase climate variability with rapid thermal fluctuations and sporadic rainfall patterns [6]. It is essential that 
genetic diversity in abiotic stress tolerance be identified and favorable genes moved into the crops of the future. The current study investigated the level of genetic diversity of two commercial sorghum hybrids to thermal and water variability. The study employed a stress bioassay that used the thermal sensitivity of the efficiency of quantum yield of photosystem II to evaluate the status of leaf tissue metabolism following growth under sub-optimal and supra-optimal temperatures and/or water-deficit stresses. The data showed that Pioneer 84G62 and Northrup King KS585 respond differently to low growth temperatures and to water-deficit stresses in the greenhouse and field.

\section{Acknowledgements}

The author thanks Jacob Sanchez, Michelle Marks, Julia Veyro and J. R. Quilan$\tan$ for their excellent assistance.

\section{Note}

Mention of a trademark, warranty, proprietary product, or vendor does not constitute a guarantee by the USDA and does not imply approval or recommendation of the product to the exclusion of others that may be suitable. USDA is an equal opportunity provider and employer.

\section{References}

[1] Burke, J.J., Mahan, J.R. and Hatfield, J.L. (1988) Crop-Specific Thermal Kinetic Windows in Relation to Wheat and Cotton Biomass Production. Agronomy Journal, 80, 553-556. https://doi.org/10.2134/agronj1988.00021962008000040001x

[2] Somero, G.N. and Low, P.S. (1976) Temperature: A "Shaping Force" in Protein Evolution. Biochemical Society Symposia, 41, 33-42.

[3] Teeri, J.A. and Peet, M.M. (1978) Adaptation of Malate Dehydrogenase to Environmental Temperature Variability in Two Populations of Potentilla glaudulosa Lindl. Oecologia, 34, 133-141. https://doi.org/10.1007/BF00345162

[4] Burke, J.J. (1990) Variation among Species in the Temperature Dependence of the Reappearance of Variable Fluorescence Following Illumination. Plant Physiology, 93, 652-656. https://doi.org/10.1104/pp.93.2.652

[5] Ferguson, D.L. and Burke, J.J. (1991) Influence of Water and Temperature Stress on the Temperature Dependence of the Reappearance of Variable Fluorescence Following Illumination. Plant Physiology, 97, 188-192. https://doi.org/10.1104/pp.97.1.188

[6] Wheeler, T. and von Braun, J. (2013) Climate Change Impacts on Global Food Security. Science, 341, 508-513. https://doi.org/10.1126/science.1239402

[7] Burke, J.J. (2007) Evaluation of Source Leaf Responses to Water-Deficit Stresses in Cotton Using a Novel Stress Bioassay. Plant Physiology, 143, 108-121. https://doi.org/10.1104/pp.106.087783

[8] Hammer, G.L., Carberry, P.S. and Muchow, R.C. (1993) Modeling Genotypic and Environmental Control of Leaf Area Dynamics in Grain Sorghum. Whole Plant Level. Field Crops Research, 33, 293-310. https://doi.org/10.1016/0378-4290(93)90087-4

[9] Prasad, P.V.V., Boote, K.J. and Allen Jr., L.H. (2006) Adverse High Temperature 
Effects on Pollen Viability, Seed-Set, Seed Yield and Harvest Index of Grain-Sorghum (Sorghum bicolor L. Moench) Are More Severe at Elevated Carbon Dioxide due to Higher Tissue Temperatures. Agricultural and Forest Meteorology, 139, 237-251. https://doi.org/10.1016/j.agrformet.2006.07.003

[10] Prasad, P.V.V., et al. (2008) Sensitivity of Grain Sorghum to High Temperature Stress during Reproductive Development. Crop Science, 48, 1911-1917. https://doi.org/10.2135/cropsci2008.01.0036

[11] Burke, J.J. and Mahan, T.C. (1993) A Controlled, Eight-Position, Thermal Plate System for Physiological Investigations. Applied Engineering in Agriculture, 9, 483-486. https://doi.org/10.13031/2013.26012

[12] Bjorkman, O. and Demmig-Adams, B. (1995) Regulation of Photosynthetic Light Ebergy Capture, Conversion, and Dissipation in Leaves of Higher Plants. In: Schulze, E.D. and Caldwell, M.M., Eds., Ecophysiology of Photosynthesis, Springer-Verlag, Berlin, 17-47. https://doi.org/10.1007/978-3-642-79354-7_2

[13] Demmig-Adams, B. and Adams III, W.W. (1992) Photoprotection and Other Responses of Plants to High Light Stress. Annual Review of Plant Physiology and Plant Molecular Biology, 43, 599-626. https://doi.org/10.1146/annurev.pp.43.060192.003123

[14] Demmig-Adams, B., et al. (1995) Xanthophyll-Cycle Dependent Energy Dissipation and Flexible Photosystem II Efficiency in Plants Acclimated to Light Stress. Aus tralian Journal of Plant Physiology, 22, 249-260. https://doi.org/10.1071/PP9950249

[15] Horton, P. (1987) Interplay between Environmental and Metabolic Factors in the Regulation of Photosynthesis in Higher Plants. In: Bihhens, J., Ed., Progress in Photosynthesis Research, Vol. II, Martinus Nijhoff Publishers, Dordrecht, 681-688. https://doi.org/10.1007/978-94-009-3535-8_161

[16] Horton, P. and Ruban, A.V. (1992) Regulation of Photosystem II. Photosynthesis Research, 34, 375-385. https://doi.org/10.1007/BF00029812

[17] Ruban, A.V. and Horton, P. (1999) The Xanthophyll Cycle Modulates the Kinetics of Nonphotochemical Energy Dissipation in Isolated Light-Harvesting Complexes, Intact Chloroplasts, and Leaves of Spinach. Plant Physiology, 119, 531-542. https://doi.org/10.1104/pp.119.2.531

[18] Maiti, R.K. (1996) Sorghum Science. Science Publishers, Lebanon.

[19] Fiedler, K., et al. (2014) Genetic Dissection of Temperature-Dependent Sorghum Growth during Juvenile Development. Theoretical and Applied Genetics, 127, 1935-1948. https://doi.org/10.1007/s00122-014-2350-7

[20] McCree, K.J., Kallsen, C.E. and Richardson, S.G. (1984) Carbon Balance of Sorghum Plants during Osmotic Adjustment to Water Stress. Plant Physiology, 76, 898-902. https://doi.org/10.1104/pp.76.4.898

[21] Three Year Summary (2011-2013) Grain Sorghum Performance Test, Hereford, Texas.

[22] Ogbaga, C.C., Stepien, P. and Johnson, G.N. (2014) Sorghum (Sorghum bicolor) Varieties Adopt Strongly Contrasting Strategies in Response to Drought. Physiologia Plantarum, 152, 389-401. https://doi.org/10.1111/ppl.12196

[23] Ogbaga, C.C., et al. (2016) Biochemical Analyses of Sorghum Varieties Reveal Differential Responses to Drought. PLoS ONE, 11, e0154423. https://doi.org/10.1371/journal.pone.0154423

[24] Stout, D.G., Kannangara, T. and Simpson, G.M. (1978) Drought Resistance of Sorghum Bicolor. 2. Water Stress Effects on Growth. Canadian Journal of Plant 
Science, 58, 225-233. https://doi.org/10.4141/cjps78-032

[25] Xin, Z., et al. (2008) A Simple Method to Determine Transpiration Efficiency in Sorghum. Field Crops Research, 107, 180-183.

https://doi.org/10.1016/j.fcr.2008.02.006 